Aleksandra Belina

Uniwersytet Warszawski*

\title{
Między wolnością badacza a pragmatyzmem. O degradacji nauk humanistycznych w obecnym dyskursie edukacyjnym
}

Between freedom of the researcher and pragmatism. On degradation of human sciences in contemporary educational discourse

Abstract

The article analyses changes in humanities in the context of growth in competitiveness and the influence of free market on education. The author examines the impact of capitalist values on the commercialized process of creation and popularization of liberal arts in Europe. She inquires if states — as leading public entities — reduce the meaning and essence of humanities. It is also argued that the trial of marketization withdrawal constitutes one of the major challenges for the representatives of the humanistic discipline. 
* Instytut Socjologii Uniwersytetu Warszawskiego ul. Karowa 18, 00-927 Warszawa adres do korespondencji: ul. Wspólna Droga 7/4, 04-345 Warszawa e-mail: olabelina@gmail.com 


\section{Zamiast wstępu. Wokół pojęcia kryzysu}

Kryzys stanowi obecnie jedną z najpopularniejszych kategorii opisujących współczesny świat. Rozpadowi ulegać zdają się dotychczas trwałe i niepodważalne struktury oraz instytucje społeczne konstytuujące — wydawać by się mogło — bezalternatywny świat: rynki kapitalistyczne, normy społeczne, procedury polityczne, formy współpracy międzynarodowej, a także sposoby myślenia o edukacji, zwłaszcza w jej wymiarze humanistycznym.

Monika Torczyńska należy do grona badaczy uznających kryzys za stan chroniczny wśród społeczeństw demokratycznych. Permanentnej obecności kryzysu towarzyszyć ma deficyt zaufania oraz niepewność.

Kryzys, zgodnie z jego etymologicznym ujęciem, kojarzyć się powinien z chwila przełomowa, z punktem zwrotnym, z wydarzeniami tak gwałtownie i dogłębnie ingerującymi w dotychczasowy sposób egzystencji danego podmiotu (zarówno indywidualnego, jak i zbiorowego), (...) że dotychczasowe reguły gry społecznej stają się nieadekwatne i należy je znacząco zrekonstruować.

(Nauki spoteczne wobec krysysu i nowych wyzwań. Teoria i praktyka 2013: 84-91)

Kryzys jest więc wydarzeniem bądź procesem gwałtownie dezorganizującym pewne aspekty ładu społecznego. Czy mamy zatem do czynienia z kryzysem nauk humanistycznych?

\section{Przyczyny kryzysu}

Źródeł aktualnej kondycji humanistyki należy upatrywać w głębokich przemianach europejskiego (i nie tylko) szkolnictwa wyższego ostatnich dwóch dekad. Marek Kwiek, filozof specjalizujący się w badaniach szkolnictwa wyższego, podkreśla wagę wzajemnych oddziaływań między instytucjami a ich zewnętrznym otoczeniem. W jego opinii uniwersytety europejskie czerpią swoje zasoby finansowe, idee założycielskie czy wreszcie społeczną prawomocność ze zmian odbywających się w świecie zewnętrznym (Kwiek 2015: 22).

Pierwsza część artykułu prezentuje zatem wybrane, pojawiające się w literaturze przedmiotu źródła kryzysu nauk humanistycznych oraz ich zależności z głębokimi przemianami sektora szkolnictwa wyższego, mającymi miejsce w drugiej połowie XX wieku w Europie. 


\section{Kryzys państwa opiekuńczego}

Przeobrażenia współczesnego uniwersytetu w wydaniu europejskim należy rozpatrywać w kontekście reform państwa dobrobytu. Jest to szczególnie istotne z uwagi na specyfikę tradycyjnych europejskich form szkolnictwa wyższego, które finansowane było przede wszystkim ze środków publicznych. Owa finansowa zależność uczelni w Europie od państwa (niewystępująca w tak dużym zakresie w Stanach Zjednoczonych) sprawiła, iż kryzys systemu opiekuńczego na Starym Kontynencie miał poważne konsekwencje w sektorze nauki.

Zanim jednak nastąpił przełom, mieliśmy do czynienia ze złotym okresem, w którym okres powojennego rozwoju szkolnictwa wyższego w Europie zbiegł się w czasie z rozwojem państw dobrobytu. Proces ekspansji sektora nauki, na który składał się wzrost nakładów na szkolnictwo wyższe i badania naukowe, wzrost współczynnika skolaryzacji, wzrost liczebności kadry, był ściśle powiązany z umacnianiem wszystkich funkcjonujących w Europie form państwa dobrobytu.

Zmiana paradygmatu myślenia o państwie opiekuńczym nastąiła na przełomie lat 70. i 80. XX wieku, po kryzysie naftowym i na fali sukcesów wyborczych Margaret Thatcher oraz Ronalda Regana. W następstwie tych zmian, a także pogłębiającego się procesu starzenia się społeczeństwa zmianie uległy priorytety państwa. Mamy współcześnie do czynienia z rosnącą konkurencją o publiczne zasoby pomiędzy sektorem szkolnictwa wyższego, systemem emerytalnym i systemem ochrony zdrowia (a także wieloma innymi obszarami aktywności państwa, np. wydatkami na cele obronne) w sytuacji zmieniających się warunków dostępności publicznego finansowania (Kwiek 2015: 51-55). W wielu krajach konkurencja wewnętrzna pomiędzy ośrodkami naukowymi na tym polu nabiera coraz bardziej agresywnego charakteru z uwagi na kurczenie się zasobów przy rosnącej liczbie kadry akademickiej. Uniwersytety coraz częściej traktuje się jako organizacje sektora publicznego, a w coraz mniejszym - jak tradycyjne, historycznie unikalne instytucje, co zmusza je do brania udziału w wyścigu o środki państwowe (Kwiek 2015: 23). Opisane zmiany ukazują kruchość uniwersyteckiego status quo, nierozerwalnie związanego i ograniczonego reformami welfare state.

Co więcej, państwa europejskie przestały obsadzać uniwersytet w roli instytucji majacej chronić i propagować kulturę narodowa, redukując tym samym jedno z historycznych uzasadnień zwiększania dotacji publicznych na rzecz sektora nauki. Kraje poszukują nowych argumentów służących uzasadnieniu finansowania uniwersytetów ze środków publicznych, związanych głównie ze sferą gospodarczą a nie kulturową (jak choćby wpływ na kompetencje siły roboczej i rozwój gospodarczy państwa, rozwój zaawansowanych technologii). Używane współcześnie argumenty odwołują się przede wszystkim do dziedzin należących do słynnej grupy STEM, na którą składają się nauki przyrodnicze (Science), technologia (Technology), inżynieria (Engineering) oraz matematyka (Math). W kontekście „Czasów STEM” („The Age of STEM”), w których żyjemy, nauki humanistyczne jawią się jako najwięksi przegrani — ich udział w publicznych nakładach na badania systematycznie maleje (por. Freeman, Marginson i Tytler 2014).

\section{Powstanie kultury audytu}

Lata 80. ubiegłego wieku były dla szkolnictwa wyższego w Europie Zachodniej okresem przekształceń w relacjach z państwem, na czele ze zmiana „społecznego kontraktu między państwem a uniwersytetem” (Kwiek 2004: 324-328). Koncepcja państwa dyscypliny 
zastapiona została przez państwo kontroli i nadzoru (por. Szadkowski 2015: 62). Zmienił się sposób dotowania nauki, w którym państwo nie tylko udziela wsparcia, lecz również dąży do ścisłej kontroli jego wykorzystania.

Wyłonił się model państwa ewaluacyjnego (i powiązanych z nim reform w paradygmacie Nowego Zarządzania Publicznego), którego zasadniczym celem jest podniesienie efektywności publicznych instytucji szkolnictwa wyższego przy jednoczesnym rozciagnięciu i utrzymaniu publicznej kontroli nad uniwersytetami; tego rodzaju kontrola realizowana jest dzięki niebezpośrednim, subtelnym mechanizmom koordynacji. Tym samym różnego rodzaju procedury oceny i mierzenia efektywności instytucjonalnej objęły sektor nauki, tworząc swoistą kulturę audytu.

Cris Shore i Susan Wright wskazują na narastający proces „rządzenia poprzez liczby”, prowadzący do redukcji złożoności procesu tworzenia i przekazywania wiedzy do uproszczonych, numerycznych wskaźników, usprawniających kontrolę systemu szkolnictwa wyższego (Shore, Wright 2015: 22).

Numeryczne wskaźniki uniwersytetów, składające się na globalne rankingi przyczyniają się do przekształcenia świata szkolnictwa wyższego, tak by „był bardziej uporządkowany na wzór konkurencyjnych rynków oraz by w coraz większym stopniu ulegał wzorcowi rządzenia właściwemu urynkowionej, konkurencyjnej oraz coraz bardziej transnarodowej organizacji” (Szadkowski, cyt. za: King 2009: 162).

Jako rezultat wymienionych przemian podaje się żądanie otrzymywania wartościowych usług za wnoszone do sektora publicznego pieniądze, wyrażające się w postawie decydentów i państwa wobec uniwersytetów (Wright i Shore 2004). Ponadto szeroko zakrojony audyt, jako przykład neoliberalnych technologii politycznych usprawniających zarządzanie w warunkach niepewności, stwarza instytucjonalną kulturę uległości. Wśród konsekwencji wprowadzenia w życie koncepcji państwa kontroli i nadzoru wymienia się również daleko idące przeobrażenia tożsamości wspólnoty akademickiej, o których mowa jest w dalszej części tekstu.

\section{Rewolucja technologiczna i tempo zmian}

Marek Wilczyński w rozważaniach wokół przemian uniwersytetu europejskiego stawia krótką diagnozę, zawierającą wątki dotychczas niepodjęte w tekście. Skupiając się w sposób szczególny na konsekwencjach dla nauk humanistycznych, autor wskazuje na trzy główne przełomy, prowadzące do opisywanego kryzysu.

Pierwszym z nich jest bezprecedensowa rewolucja technologiczna, powiązana z popularyzacją internetu na masową skalę, która spowodowała utożsamienie wiedzy z informacją przed której nadmiarem coraz trudniej się bronić.

Badacz dodaje również, iż szybkość zmian cywilizacyjnych dostarcza świadomości niespotykanych dotychczas różnic między teraźniejszością a przeszłością, deprecjonując znaczenie przeszłości, historii, odgrywającej w naukach humanistycznych kluczową rolę.

Ostatni zwrot dotyczy reform modelu edukacji na poziomie podstawowym i średnim, które nierzadko są marginalizowane w dyskusjach dotyczących szkolnictwa wyższego. W opinii badacza przemiany w kierunku rozpowszechnienia numerycznych egzaminów oraz testów z kluczem, a także wypierania opinii indywidualnych, nieszablonowych, prowadzą do zawężenia grona uczniów zainteresowanych zgłębianiem wiedzy humanistycznej (Humanistyka z widokiem na uniwersytet 2016: 102). 
Abstrahując od pytania, czy mamy do czynienia z kryzysem o wyjątkowej, nieznanej dotychczas skali, czy też kolejnym, wpisanym w rozwój cywilizacyjny rytuałem przejścia, w dyskursie publicznym coraz częściej podejmuje się dyskusję dotyczącą kształtu (post) nowoczesnego uniwersytetu w kontekście narodzin kapitalizmu akademickiego.

\section{Komercjalizacja nauki — narodziny kapitalizmu akademickiego}

Kolejne części artykułu dotyczą jednego z aspektów przemian (po)nowoczesnego uniwersytetu, jakim są narodziny i rozwój kapitalizmu akademickiego.

Część badaczy wskazuje na wejście systemów szkolnictwa wyższego w fazę drugiej rewolucji akademickiej (Etzkowitz 2002: 9-19). Rosnąca globalizacja doprowadzić miała do rozkładu profesji uniwersyteckiej i narodzin kapitalizm akademickiego, definiowanego jako ,instytucjonalne oraz profesjonalne działania rynkowe i rynkopodobne mające na celu zapewnienie środków zewnętrznych" (Szadkowski, cyt. za: Leslie i Slaughter 1998: 8).

Komodyfikacja edukacji odnosi się do świadomego procesu przeobrażania kształcenia w formę towaru w celu dokonania komercyjnej transakcji. Wiąże się z przerwaniem i dezintegracja procesu edukacyjnego oraz unifikacją doświadczenia poznawczego, konstruowanego w postaci sprzedawalnych pakietów. Cel edukacji z samopoznania przesuwa się ku akumulacji zysków. Proces ekonomizacji nauki można rozpatrywać w dwóch uzupełniających się wymiarach. W pierwszym z nich edukacja traktowana jest jako składnik rozwoju gospodarczego, w drugim — sama zostaje obiektem zarządzania prowadzącego do jej ekonomicznej racjonalizacji. W wyniku hegemonii dyskursu kapitalistycznego oba czynniki traktowane są jako równoległe, uzupełniające się, choć w rzeczywistości drugi nie musi być konsekwencja pierwszego. Uczestnicy edukacji stają się zakładnikami machiny rynkowej, utwierdzając w sobie konieczność następowania po sobie obu aspektów ekonomizacji nauki. W przeszłości wobec uczelni stawiano zarzuty separatyzmu, izolacji od społeczeństwa i jego problemów. Dziś uniwersytet jest jedna z licznych instytucji społecznych, której działania postrzega się w kategoriach dostarczania usług i produktów.

Komercjalizacja, silnie wiążąc edukację z rynkiem, powoduje ograniczenie i selektywny dobór treści nauczania. Zostają one podporządkowane wymogowi produktywności, a ich wybór wynika z reguł o charakterze ekonomicznym. Komodyfikacja sprzyja konsumpcyjnemu nastawieniu wobec wiedzy i edukacji. W wyniku postępujących procesów urynkowienia zmieniają się kryteria oceny szkół i uczelni — nierzadko zostają one sprowadzone do miejsc w rankingach, których istotnym wymiarem jest właśnie wymiar konsumpcyjny. Przerywany jest wartościowy przekaz pokoleniowy, odsunięta refleksyjność, konstytuujaca uczelnię jako instytucję krytyczną, tworzącą dyskursy. Proces kapitalistyczny nie tylko „przekształca (...) metody realizacji wyznaczanych celów, ale także wpływa na zmianę struktury samych celów" (Schumpeter 2009: 151).

W głośnym studium Marthy Nussbaum Nie dla zysku autorka stawia tezę o istnieniu globalnego „cichego kryzysu”, prowadzącego do kształcenia użytecznych, pragmatycznych podmiotów, zamiast obywateli zaangażowanych, krytycznie myślących, samodzielnych. Konsekwencją jest zagubienie we współczesnym świecie pluralistycznych wartości, redukcja ludzi do homines oeconomici, dezorientacja związana z brakiem sensu kształcenia, gorączka dochodowości, orientacja na zysk (Nussbaum 2016).

Zasadniczym procesem, jaki dotyka polskie szkolnictwo wyższe, począwszy od lat 90. $\mathrm{XX}$ wieku, jest szeroko pojęta komercjalizacja, polegająca na traktowaniu edukacji jako 
inwestycji na przyszłość (mającej wesprzeć karierę zawodowa), dyplomu jako towaru rynkowego, a sektora edukacji jako gałęzi gospodarki rynkowej. Przedmiotem komodyfikacji jest także urynkowienie szkolnictwa wyższego, definiowane jako proces adaptowania się uniwersytetów do funkcjonowania według zasad i w warunkach konkurencji wolnorynkowej. Zjawisko to objawia się stopniowym przekształcaniem szkół wyższych w przedsiębiorstwa, występujące w postaci usługodawców dla studentów-klientów. Za fundament wspomnianego procesu uchodzi powstanie niepublicznych szkół wyższych, przynajmniej ilościowo stanowiących realną konkurencję dla szkół publicznych (Misztal 2000: 27; Antonowicz 2005). Konsekwencją nienormowanego wzrostu liczby uczelni, umożliwiających zdobycie wyższego wykształcenia (a tym samym kredencjałów gromadzonych przez młodych uczestników rynku pracy) jest spadek wartości, prestiżu dyplomów ukończenia studiów. Według Randalla Collinsa dobra produkowane w nadmiarze (do których należą w Polsce obecnie dyplomy licencjata i magistra) dotyka inflacja, przyczyniająca się do rosnących nierówności społecznych i uniemożliwiająca zapewnienie wartościowej edukacji dla społeczeństwa, ze względu na zaniżony poziom — jedynie mały odsetek studentów otrzymuje odpowiednią jakość wykształcenia (Collins 1979: 191-204).

\section{Ideologiczny kontekst przemian — edukacja (meta)polityczna}

Według węgierskiego socjologa, Karla Mannheima, ideologie oznaczają „sposób, w jaki spoglądamy na przedmioty, postrzegamy je i konstruujemy w myśleniu. Nie są jedynie formalna, lecz przede wszystkim jakościową determinacją myślenia” (Mannheim 2008: 362). Ideologia dostarcza uzasadnienia, legitymizacji, cementuje grupową i jednostkową tożsamość, jest matrycą konstytuująca tworzenie świata społecznego. Opisywane przemiany szkolnictwa wyższego nie tworzą się w próżni, lecz afirmowane są, jednocześnie wynikając, z konkretnej wizji rzeczywistości. Nauka nie jest wolna od presji panującej ideologii, co skutkuje tym, że uczelnia przekazuje, jednocześnie utrwalając, reguły życia społeczno-ekonomicznego. Tym samym uniwersytet przyczynia się do reprodukcji istniejącego ładu. Jak twierdzi Krystian Szadkowski: „,nowe idee prowadzące do zmiany w całościowym modelu funkcjonowania państwa i usług sektora publicznego w Europie niosą ze sobą daleko idace konsekwencje dla funkcjonowania uniwersytetów europejskich" (Szadkowski 2015: 23).

Dominacja „logiki produktywności” widoczna jest w rządowych planach reform i w strategicznych dokumentach dotyczacych rozwoju szkolnictwa wyższego, w których kładzie się szczególny nacisk na propagowanie treści przydatnych ekonomicznie, na wspieranie kierunków silnie związanych z przemysłem technologicznym oraz na ograniczanie dostępu do kierunków z ekonomicznego punktu widzenia mniej przydatnych czy po prostu zbędnych. W 2000 roku Unia Europejska określiła „gospodarkę opartą na wiedzy" jako podstawę strategii rozwoju gospodarczego. W świetle strategii lizbońskiej edukacja ma być źródłem przewagi ekonomicznej, innowacyjności i rozwoju gospodarczego (Co dalej ze strategia liz̧bonskaq? 2008). Uniwersytet zdaje się tracić dotychczasowe miejsce w społeczeństwie. Pogłębiona refleksja czy namysł nad rzeczywistością zostaja poddane dyskursowi konkurencji. W Polsce o tych przemianach mówią głośno (jednocześnie manifestując sprzeciw) członkowie licznych ruchów społecznych, jak choćby Obywatele Nauki, Komitet Kryzysowy Humanistyki czy, działający w Warszawie, Uniwersytet Zaangażowany. 
Projekt działania uniwersytetu według Wilhelma von Humboldta zmierzał ku pogodzeniu autonomiczności uczelni oraz celów stawianych przez państwo, dążył do sytuacji konsensusu pomiędzy niezależnością procesu poznania i pragmatycznymi naciskami podmiotu posiadającego monopol na użycie przymusu. Ów schemat powielany był przez kolejne dziesięciolecia, aż do czasu znaczących, opisanych wyżej przemian, które dokonały redefinicji relacji uniwersytetu z aparatem państwowym. Współcześnie transformacja więzi między uniwersytetem a kluczowymi podmiotami życia publicznego zachodzi w wyniku dominacji dyskursu kapitalistycznego.

\section{Konsekwencje przemian na poziomie jednostkowym $\mathrm{i}$ instytucjonalnym}

Nauka uprawiana pod presją zmian gospodarczych jawi się w opinii wielu badaczy jako szczególnie niebezpieczna. Kozyr-Kowalski twierdzi, iż

[w]ypieranie bezinteresownego poszukiwania prawdy materialnej i rzeczowej, merytorycznej wiedzy o świecie przez naukę-służebnicę biznesu i bezpośrednio pojętej użyteczności zawodowej stanowi o wiele większe niebezpieczeństwo dla cywilizacji współczesnej niż degradowanie nauki do roli służebnicy teologii lub państwa. (Kozyr-Kowalski 2005: 52)

Władza rachunku ekonomicznego uzyskała zdolność kolonizacji wszystkich sfer życia społecznego, w tym pracy uczelni.

$\mathrm{Na}$ tle globalnych przemian szkolnictwa wyższego Polskę charakteryzuje specyficzny kontekst historyczny. Lata walki o autonomię myślenia zwieńczone zostały niepohamowanym napływem mechanizmów wolnego rynku i wdrożeniem ich w aparat biurokratyzacji. Z perspektywy czasu widać wyraźnie, że zapotrzebowanie na edukację (sprowadzoną nierzadko do systemu certyfikacji) nie było tożsame z zapotrzebowaniem na wiedzę. Rosnąca liczba absolwentów nie zapewniła nowej, pozytywnej jakości w edukacji, lecz w dużej mierze odarła wiedzę z jej emancypacyjnego charakteru. Tym samym weryfikacji poddano przekonanie, że podniesienie współczynnika skolaryzacji (rozumianego statystycznie, a nie jakościowo) może być substytutem innych kryteriów awansu cywilizacyjnego społeczeństwa. Według Andrzeja Mencwela mamy do czynienia z „fetyszystycznie pojmowana modernizacją", prowadząca do biurokratycznej formalizacji i kwantyfikacji wszystkiego, reżimu punktacji oraz osłabienia zdolności samodzielnego, oryginalnego myślenia (Uniwersytet zaangażowany. Przewodnik Krytyki Politycznej 2010: 18).

Presja ekonomiczna powoduje szereg dalekosiężnych zmian, o których piszą między innymi Brown i Clignet, twierdząc, że badania w coraz mniejszym zakresie podlegaja wewnętrznym standardom doskonałości, włączając zasady etyczne, co prowadzi do nieuchronnej ich demoralizacji. W miejsce dotychczasowych kryteriów pojawiają się wskaźniki dotyczące wielkości funduszy, efektywności rezultatów czy bezpośredniej użyteczności badań w ramach status quo ustalonego przez rządy i korporacje (Brown i Clignet 2000: 38-41).

Instrumentalizacja kształcenia uniwersyteckiego stoi w opozycji do postulatu wytworzenia uczelni pełniącej rolę swoistej enklawy, duchowego kontestatora kultury masowej, korporacyjności. Instytucji zapewniającej równowagę i pogłębioną refleksję młodym adeptom, zanurzonym w płynnej nowoczesności. Co więcej, wąsko rozumiana komercjalizacja przyczynia się do istnienia komercjalizacji o szerokim znaczeniu, objawiającej 
się między innymi dominacją logiki zysków i start, która wypiera poznanie jako wartość samą w sobie w rozważaniach o edukacji (Edukacja. Przewodnik Krytyki Politycznej 2013: 78). W konsekwencji nauka traci metafizyczny sens, moralną podbudowę.

Debata publiczna dotycząca edukacji została zdominowana przez pojęcia ekonomiczne, jak choćby: usługi, innowacje, kapitał (ludzki i społeczny), inwestycje, przedsiębiorczość, efektywność, ranking. Zjawisko to nazwane zostało przez Tomasza Szkudlarka kolonizacją dyskursu (Fenomen nierówności społecznych 2007). Wśród przywołanych terminów szczególną uwagę zwracają rankingi i ich rola w jednoczesnym ukazaniu i ukierunkowaniu uczelni na wysiłki marketingowe, zorientowane na zrekrutowanie nowych studentówkonsumentów (Welch 1997: 299-303).

Według niektórych postulatów uniwersytety powinny spełniać sprzeczne ze sobą cele: gwarantować dostęp do rynku pracy (będącego przestrzenią indywidualnej konkurencji), budując jednocześnie wspólnotę opartą na tradycyjnych wartościach (Syska 2010: 8). W rzeczywistości uniwersytety stają się miejscem sacrum i profanum, traktowanym przez niektórych niczym dom towarowy, moment przejścia konieczny do uzyskania odpowiedniego dokumentu, pozwalającego na (rzekomo) lepszy start w karierze zawodowej. Jak trafnie zauważa Altbach, urynkowienie edukacji zmienia postawę społeczeństwa, postrzegającego wiedzę akademicką jako nie dobro wspólne, a prywatne, instrumentalne narzędzie sukcesu (2001: 3-4). Jednocześnie rozwija się problem prywatyzowania odpowiedzialności za oświatę.

Daria Hejwosz-Gromkowska wspomina o redukcji społecznej (jak i ekonomicznej) odpowiedzialności pod wpływem supremacji wiary w siły rynkowe. Mamy zatem do czynienia z paradoksem wolności pozbawionej odpowiedzialności zbiorowej i indywidualnej, wolności pozornej, zredukowanej. Jak twierdzi:

[w]ielu badaczy zajmujących się problematyką szkolnictwa wyższego przedstawia dystopijną wizję szkolnictwa wyższego. Jednak to oni walczyli o obalenie wieży z kości słoniowej, jaką był uniwersytet. Wywalczono równość, wprowadzono zasady merytokratyczne, zniesiono arbitralność władzy i autorytetu. Z całą pewnością te rewolucyjne przemiany zmieniły uniwersytety na lepsze. Georges Danton powiedział, że „Rewolucja, jak Saturn, pożera własne dzieci”.

(Hejwosz-Gromkowska 2014)

W narastającej symbiozie uczelni i sektora biznesowego dostrzec można również pozytywne konsekwencje. Wśród nich wymienia się wzrost przedsiębiorczości niektórych szkół wyższych w poszukiwaniu możliwości dywersyfikacji źródeł finansowania i inwestowaniu w badania oraz projekty współpracy z podmiotami z trzech sektorów. Opisane implikacje, choć istotne z punktu widzenia ryzyka alienacji uniwersytetu, nie dają gwarancji zapewnienia historycznej ciagłości i stabilności uczelni.

\section{Urynkowienie świadomości}

Edukacja stanowi jedną z kluczowych przestrzeni kształtowania się tożsamości. Jednym z cytatów otwierających studium Marthy Nussbaum Nie dla zyskeu jest fragment książki Nacjonalizm Radindranatha Tagore z 1917 roku: 
zanika człowiek moralny, człowiek zupełny. Ustępuje on miejsca człowiekowi (...) handlowe$\mathrm{mu}$, człowiekowi o celach ograniczonych. Proces ten, dzięki cudownemu niemal rozwojowi wiedzy, przybiera coraz potężniejsze rozmiary, powodując upadek równowagi etycznej, cieniem bezdusznej organizacji przesłaniając to, co jest ludzkim w człowieku. (Nussbaum, cyt. za: Tagore 1992: 16)

W sytuacji, w której konsumpcji ulega każdy wymiar życia, obywatelskość traci. Konsument staje w opozycji do aktywnego obywatela poprzez deprywację potrzeby uczestnictwa w życiu publicznym. W miejsce zaangażowania wchodzi imperatyw nieustającego, bezrefleksyjnego wybierania i używania wszystkiego czego zechce, ciagle od nowa. Słusznie zauważa Alicja Kargulowa, uznając, że:

[edukacja] traktowana jako usługa stara się zaspokajać zachcianki klienta, dogadzać mu, odciągając jego uwagę od jakiegokolwiek wartościowania czy przeżywania dylematów moralnych, sprzyja powstawaniu jedynie iluzji prawa wyboru działań, zachowań, doznań. (...) Wybierając odpowiednią formę edukacji i próbując z niej korzystać, dba o sprawianie dobrego wrażenia.

(Rynek i kultura neoliberalna a edukacja 2005: 208)

Za opisywanymi przemianami kryje się „komercjalizacja tożsamości” studentów i badaczy, o której wspomina Zbyszko Melosik. Komercjalizacja owa wyrażana jest w pragnieniu zdobycia kompetencji umożliwiających sukces na rynku pracy. Paradygmat przydatności tworzy model absolwenta wyspecjalizowanego pragmatyka, elastycznego eksperta, posługującego się wiedzą o określonej wartości na rynku, technicznie użyteczną. „Młodzi naukowcy traca najważniejsze lata swojego rozwoju intelektualnego, poszukując szybkich dowodów osiąnnięć i zaniedbują — wymagające dłuższego czasu — kultywowanie bardziej ambitnych i głębokich projektów” (Melosik 2009: 62). Marta Opiłowska, opisując konsekwencje komodyfikacji szkolnictwa wyższego w Polsce, wspomina o redefinicji „tradycyjnych ról”: student stał się klientem, a uniwersytet wraz z zatrudnioną kadrą zaczął pełnić funkcję usługodawcy, wystawiającego „fakturę” w postaci dyplomu ukończenia studiów wyższych (Opiłowska 2009: 109). W świetle przeprowadzonych badań stawia hipotezę o pragmatycznej kalkulacji studentów, „która wyraża się w przedkładaniu zysków nad straty, bez względu na to, jakie są korzyści i koszty" mimo deklaratywnej altruistycznej motywacji do zdobywania kredencjałów (Opiłowska 2009: 125).

Krytyka współczesnego kształtu kariery akademickiej zasadza się również na ocenie prestiżu i pozycji naukowej badacza, które wynikają w coraz większym stopniu z umiejętności autoreklamy wraz z wyborem „odpowiedniego” przedmiotu badań, wpisującego się w rynkowe kryteria szybkich efektów i dużego zwrotu z inwestycji (Nevo i Nevo 1996: 173). Ekonomiczne kryteria powinny jednakże w dłuższej perspektywie być zbieżne z kryteriami sensu stricto naukowymi (poziomem badań naukowych). Joanna Rutkowiak bardzo radykalnie podsumowuje spotkanie neoliberalizmu z edukacją:

Napór idei i empirii edukacyjnego programu ekonomii korporacyjnej pojmuję jako jej zwielokrotniony nacisk na ludzi realizowany przez instrumentalne oddziaływania perswazyjne typu psychologicznego i ideologicznego połączone z oddziaływaniami rzeczowymi typu materialnego. (...) Objawia się to albo w zinterioryzowaniu akceptacji i uprawianiu konsumpcjonizmu jako jedynej możliwej jakości życia, z rezygnacją z innych perspektyw, albo w przeżywaniu ambiwalencji, z uprawianiem zachowań nieradykalnie konsumpcyjnych, którym towarzyszy wahliwość aprobaty wewnętrznej. (Rutkowiak 2008:15) 
Tożsamość funkcjonalna wobec systemu, narzucanej ideologii, wyraża się między innymi w zaszczepianiu ,jednostce rynkowego poglądu na świat i własne w nim miejsce”" (Lewartowska-Zychowicz 2010: 33). Kultura indywidualnego sukcesu zastąpiła klasyczną ideę emancypacji jednostkowej związanej z podejmowaniem społecznych zobowiązań, braniem odpowiedzialności za kształt wspólnoty i miejsce jednostki w niej (Lewartowska-Zychowicz 2010: 12). Idee wspólnotowości i współodpowiedzialności przysłoniła efektywność, rywalizacja oraz tendencja do poszerzenia zakresu wolności jednostkowej.

Hegemonia liberalnego dyskursu, tworząca opisany projekt tożsamości, nie powinna być jednakże traktowana jako porządek trwały, jako kolejny element bezalternatywnej rzeczywistości. Imperatyw komodyfikacji szkolnictwa wyższego spotyka się w ostatnich latach z globalnymi ,narzędziami oporu” w postaci, nierzadko organizowanych na masową skalę, protestów (por. Buckleyjan 2012; Cummings 2015; Palacios-Valladares 2015; Ransby 2015; Schmidt 2014; Wond 2015) postulujących — z różnych punktów widzenia i przesłanek - namysł nad kontekstem i negatywnymi konsekwencjami urynkowienia szkolnictwa wyższego.

\section{Próby odpowiedzi na „kryzys”. W obronie humanistyki (i nie tylko)}

Przeobrażenia i potrzeby skonfigurowanej sfery gospodarczej, politycznej i społecznej determinują kształt wyzwań, z którym mierzyć musi się współczesny uniwersytet. Należy zastanowić się nad adekwatnością klasycznej wizji uczelni w nowym, zmieniającym się dynamicznie otoczeniu. Ani radykalne dopasowanie idei uniwersytetu do „wymagań” rynku, ani obrona odizolowanego, niepodważalnego, uświęconego uniwersytetu jako wieży z kości słoniowej nie jest właściwą drogą przemian.

Podnoszony coraz częściej postulat wyważonej refleksji, interakcji między dwoma krańcami kontinuum, zdaje się być adekwatną, choć nie jedyną, drogą odejścia od całkowitej hegemonii rynku w myśleniu o nauce, a zwłaszcza o naukach humanistycznych. Stopniowa redefinicja roli uniwersytetu jako instytucji społecznie użytecznej, posiadającej moc utrzymania funkcji emancypacyjnej dotyka w sposób najciekawszy i najpełniejszy sedna problemu. Jak wspomina Tomasz Bilczewski:

(...) proces urynkowienia wiedzy można zorganizować tak, by przebiegał z szacunkiem dla niekomercyjnych, często tylko pozornie nieopłacalnych funkcji uniwersytetu, by nie ograniczał roli nauki do wykalkulowanej praktyki mającej na celu jedynie wytwarzanie dóbr, na które istnieje aktualne, niejednokrotnie ściśle polityczne zapotrzebowanie. (Wolność, rómność, uniwersytet 2011: 36)

Uczelnie winny pozostać miejscem badań zarówno stosowanych, jak i podstawowych, fundamentalnych, prowadzących do zadawania na nowo i redefiniowania kluczowych pytań o naturę rzeczy, odsłaniających nowe horyzonty myślowe, kształtujących debatę publiczną i wzmacniających etykę obywatelską. Istotne w społeczeństwach demokratycznych wartości, związane są wszakże z naukami humanistycznymi: zdolność do krytycznego myślenia i wykroczenia poza więzy lokalne i spojrzenia na globalne problemy z perspektywy „obywatela świata”, zdolność do współczucia i zrozumienia trudnej sytuacji drugiej osoby (Nussbaum 2016: 23).

W posthumboldtowskim modelu uczelni do tradycyjnych celów, takich jak kształcenie i prowadzenie badań, zostały dodane nowe, w tym także wspomniana „trzecia misja”, czyli tworzenie 
powiązań między uniwersytetem a otoczeniem, oraz zawierająca się w niej „misja cywilna”, service to society, określająca zadania uniwersytetu we współczesnych demokracjach, skupiająca się m.in. na edukacji publicznej. (Wolność, równość, uniwersytet 2011: 10)

W tym ujęciu kładzie się szczególny nacisk na praktyczny aspekt wiedzy, który winien wyrażać się poprzez uczynienie z niej narzędzia samoświadomości, emancypacji społecznej. Uczelnie powinny, zwłaszcza w kontekście rosnącej komercjalizacji i pragmatyzacji zachowań, pełnić funkcję changemakers, aktywnych i elastycznych podmiotów, stale reagujących na rodzące się wyzwania społeczne, ekonomiczne, polityczne czy kulturowe. Tylko w ten sposób mogą konsekwentnie realizować tzw. trzecią misję, podkreślającą znaczenie makrostruktury uczelni, uniemożliwiając jej pozostanie samotną wyspą na tle przeobrażeń społecznych.

By sprostać tym wyzwaniom, będącym pewnym kompromisem między tradycyjnie ujmowaną rolą uniwersytetu a (post)nowoczesnymi wyzwaniami globalnego rynku, próbą skonstruowania synergii, ośrodki naukowe i badacze potrzebują szeroko rozumianej, silnej autonomii. Niezależność decyzyjna na poziomie jednostkowym i instytucjonalnym może być warunkiem do tworzenia uniwersytetu, będącego ważnym podmiotem, dbajacym zarówno o holistyczny rozwój ludzkich umysłów i kształtowanie krytycznych, empatycznych obywateli (nie-konsumentów), jak i związki nauki z gospodarczym otoczeniem. Efektywność ekonomiczna nie powinna zostać jednakże wyniesiona na piedestał, stając się kluczowym elementem oceny uniwersytetów i kierunkiem ich rozwoju.

Interes ekonomiczny wymaga oparcia się na naukach humanistycznych — dzięki nim możliwe jest stworzenie warunków do odpowiedzialnego i uważnego zarządzania oraz rozwój kultury sprzyjającej innowacjom. Nie trzeba dokonywać wyboru między typem edukacji promującym zysk a tym, który sprzyja dobremu obywatelstwu. Dobrze rozwijająca się gospodarka potrzebuje umiejętności, które wzmacniają obywatelskość, stoją na straży ustroju demokratycznego, etyki obywatelskiej, debaty publicznej. Celem uczelni powinno być nie tylko wytwarzanie i upowszechnianie wiedzy, lecz także zaangażowanie w życie wspólnoty, krzewienie i wsparcie postaw krytycznych, twórczych - a przecież tym samym - bardziej innowacyjnych, nierzadko w konsekwencji bardziej konkurencyjnych i autorefleksyjnych zarazem. Wspominana już filozofka i etyczka, Martha Nussbaum, twierdzi, że „[w] wyścigu za innowacyjnością nie wolno zlekceważyć wysiłku zrozumienia rzeczy, które nas otaczaja; to domena szeroko rozumianej działalności humanistycznej i artystycznej” (2016: 27). Za jeden z wielu inspirujących przykładów niech posłuży teoria widzenia Strzemińskiego (artysty o gruntownym wykształceniu humanistycznym), wyprzedzająca o kilkadziesiąt lat odkrycia neuropsychologów i neurobiologów na temat ludzkiej percepcji (Teoria widzenia 2016). Co więcej, instrumentalizacja kształcenia uniwersyteckiego redukuje zdolności uczelni do bycia mądrą wspólnotą. Według Przemysława Plucińskiego „[p]roblem kryzysu współczesnego uniwersytetu nie może być (...) wpisany wyłącznie w kontekst instrumentalizacji uniwersytetu, nauki i poznania oraz ich utowarowienia”. Należy pamiętać, że „,[p]raca filozofa czy artysty nie daje się przełożyć na system instrumentów usprawniających nasze życie, ale to ona stwarza bogactwo, z którego czerpie człowiek, chcą być człowiekiem pełniejszym, człowiekiem uznającym swoje życie za lepiej spełnione ku pożytkowi własnemu i innych" (Wolność, równość, uniwersytet 2011: 27). Nie należy zatem zagubić wrażliwości, pierwiastka decydującego i konstytuującego nasze bumanitas w drodze ku konkurencyjności i efektywności. 
Interesującą wizję przemian uniwersytetu (i myśleniu o nim) przedstawia Krystian Szadkowski, proponując reżim dóbr wspólnych, wykraczający poza dychotomiczny spór dotyczący przyszłości szkolnictwa wyższego (utopijny powrót do korzeni versus dalsza komercjalizacja i komodyfikacja). W jego ujęciu (sięgającym do idei ekonomii współpracy) uniwersytet ma być instytucją dobra wspólnego, częścią kooperatywnego szkolnictwa wyższego, redukując prymat zasad konkurencji i własności (Szadkowski: 2015: 277-295). Uczelnia może stać się liderem przemian społecznych nie poprzez replikację powszechnych, ukonstytuowanych reguł gry, lecz dzięki działaniom z wnętrza systemu, na obrzeżach istniejących schematów, w duchu idei Martina Heideggera, iż „największe idee zjawiają się niepostrzeżenie" (Heidegger 2002: 49). Nieustanny udział wspólnoty akademickiej w twórczym procesie kreacji „,największych idei”, na przekór erozji funkcji intelektualnych i kulturowych uniwersytetu, której świadkiem jesteśmy, jest jedną z tych aktywności, dzięki którym uczelnie pozostają istotnym podmiotem życiem publicznego. Uniwersytet powinien, mimo to, odpowiedzieć na rodzące się wyzwania późnej nowoczesności, zanurzonej w etyce kapitalizmu. Jednym z jego celów, jako instytucji publicznej, wspólnotowej, winno być zarówno służenie społeczeństwu, jak i wysuwanie krytyki wobec jego mechanizmów. Imperatyw ten nie będzie mógł być jednak spełniony, jeśli uczelnia stanie się na nowo wieżą z kości słoniowej, a jej członkowie — gatunkiem homo academicus (Mayor 1989: 16).

Jak twierdzi Tadeusz Sławek: „uniwersytet musi (...) respektować prawa rynkowej ekonomii, lecz nie wolno mu przystać na to, aby ekonomia stała się jedynym regulatorem życia uniwersyteckiego i społecznego" (Sławek 2002: 31). Nie wolno zaakceptować stanu, w którym utilitas zawłaszcza i redukuje curiositas, postawę jednostki refleksyjnej, pytającej, świadomej swych ograniczeń i swej niewiedzy. Wszakże „[p]ołączenie potrzeby użyteczności i idealistycznego dążenia do odsłaniania prawdy leży u podstaw instytucji uniwersytetu, w samym jej sercu (...)” (Kościelniak i Makowski 2011: 39). Konkurencyjność stała się faktem, immanentną cechą współczesności, od której uniwersytet, jako instytucja społeczna nie może i nie jest w stanie uciec. Zamiast wybrać drogę bagatelizowania społeczno-ekonomicznych przemian i drogę ucieczki, uczelnie muszą zmierzyć się z nowopowstającymi wyzwaniami. Status uczelni nie daje uprawnień do lekceważenia świata (przywołując wspomniane niebezpieczeństwo alienacji), lecz wymaga stałego z nim kontaktu i uczestnictwa w jego scenariuszach. Należy zatem bronić autonomiczności, nie w sposób bierny i bezrefleksyjny, lecz dbając jednocześnie o rozważne sposoby zarządzania własną strukturą oraz dobierać partnerów z sektora publicznego, biznesowego oraz pozarządowego, nie zapominając przy tym o wartości, jaką jest nauka sama w sobie. Według Stanisława Kozyra-Kowalskiego „[e]lementarną funkcją uniwersytetów i szkół wyższych nie jest dotrzymywanie kroku zmianom koniunktur gospodarczych, lecz wyprzedzanie tego rodzaju zmian” (Kozyr-Kowalski 2005: 52), urzeczywistniające się w dostarczaniu i dążeniu do wiedzy relatywnie wyspecjalizowanej o charakterze uniwersalnym. Cechą szczególną tego typu wiedzy jest wielofunkcjonalność, swoista innowacyjność, możliwość zastosowania do zupełnie nowych problemów i wyzwań.

\section{Zamiast zakończenia. Humanistyka jako nauka adekwatna $\mathrm{i}$ istotna}

Kryzys państwa opiekuńczego znacząco wpłynął na pejzaż i reformy szkolnictwa wyższego w Europie, skutkując przemianami w sposobie finansowania sektora nauki. W ciagu ostatnich dwóch dekad rosło znaczenie konkurencyjności oraz ekonomicznej wartości 
uniwersytetu w uzasadnianiu i uprawomocnianiu dotowania akademii ze środków publicznych. Przemiany państwa dobrobytu i szkolnictwa wyższego drugiej połowy XX wieku posiadają strukturalne podobieństwa w następujących po sobie epoce ekspansji i epoce oszczędności. Wyzwania, przed którym stoi welfare state — zmiany demograficzne, gospodarcze, polityczne i społeczne przyczyniają się do rosnącej presji finansowej, odczuwalnej w sektorze nauki, a w sposób szczególny — wśród wspólnoty akademickiej, zajmującej się humanistyka.

Funkcjonując w obecnym systemie ekonomiczno-społeczno-politycznym, europejska kadra akademicka jako znaczacca grupa interesu powinna

w jasny sposób wykazywać niekwestionowaną dotąd (...) wartość dostarczanych usług edukacyjnych i badawczych. Najważniejszą kwestią dla społeczeństwa i decydentów politycznych staje się coraz wyraźniej wartość wszystkiego tego, co jest w stanie wytworzyć szkolnictwo wyższe, która jest relatywna wobec wartości rezultatów społecznych możliwych do osiagnięcia przy wykorzystaniu tych samych zasobów finansowych gdzie indziej. (Kwiek 2015: 34)

Wśród wspólnoty akademickiej nie ma jednakże konsensusu dotyczącego zgody na przystosowawczy charakter działań. Wielu jej członków proces komodyfikacji rzeczywistości uniwersyteckiej (w tym uzasadniania prowadzenia badań poprzez użycie argumentów natury ekonomicznej) opisuje w kategoriach współczesnego kryzysu edukacji, a w szczególności - humanistyki, wiedzy o charakterze emancypacyjnym i bezinteresownym. Krystian Szadkowski stwierdza wręcz, że globalny wyścig o prestiż (a tym samym obecnie — o środki, dotacje, miejsce w rankingach) jest jedną z podstawowych blokad rozwoju nauki i edukacji wyższej (Szadkowski 2015: 273).

Mając to na uwadze, warto rozwijać i podkreślać rolę zaangażowanych społecznie, nowych nurtów badań humanistycznych, które za cel stawiaja sobie tworzenie wiedzy stosowanej, wraz z wprowadzaniem zmian w społeczeństwie. Eksponowany winien być proces tworzenia związków między humanistyką a funkcjonowaniem etycznym jednostek i wspólnot, który Ewa Domańska określa jako „zwrot ku sprawczości” (the agentiveturn). Dzięki niemu tworzy się przestrzeń dla buntów, rewolucji (będących częścią obecnego pejzażu społecznego), a podmiot zyskuje siłę sprawczą (Domańska 2007: 56).

Wydaje się, że bez radykalnej transformacji społeczeństwa jako całości, uniwersytet, będący integralną częścią kapitalistycznego sposobu produkcji, nie może przejść trwałej przemiany. Pierwsze — choć jeszcze nie wystarczające, by zmienić rzeczywistość społeczną - oznaki buntów obserwujemy podczas masowych protestów w Stanach Zjednoczonych, Wielkiej Brytanii, Meksyku, Wenezueli i innych krajach, w których kapitalizm akademicki spowodował głębokie przemiany w sposobie myślenia i uprawiania nauki. Kryzys może bowiem okazać się cykliczną determinantą zmiany, punktem zwrotnym, a nie preludium klęski.

Odwołując się do słów Henryka Elzenberga, „[w]alka beznadziejna, walka o sprawę z góry przegraną bynajmniej nie jest poczynaniem bez sensu. (...) Wartość walki tkwi nie w szansach zwycięstwa (...), ale w wartości tej sprawy" (Elzenberg 1994: 368-369). Stawką w tej walce ,jest obrona humanistyki jako wiedzy adekwatnej — to znaczy pozwalającej nam odnaleźć się w świecie — oraz istotnej, czyli dającej coś, czego nie może dać nic innego poza nią" (Sowa 2014: 194). 


\section{Bibliografia}

Antonowicz Dominik (2005), Uniwersytet prazyszłości. Wyzwania i modele polityki, Instytut Spraw Publicznych, Warszawa.

Brown Richard H., Clignet Remi (2000), Democracy and Capitalism in the Academy: the Commercialization of American Higher Education [w:] Knowledge and Power in Higher Education, red. R.H. Brown, J.D. Schubert, Teachers College, New York-London.

Buckleyjan Cara (2012), The New Student Activism, http://www.nytimes.com/2012/01/22/ education/edlife/the-new-student-activism.html?_r=0 [dostęp: 17 sierpnia 2017].

Collins Randall (1979), The Credential Society, New York Academic Press, New York.

Cummings Peter M.M. (2015), Democracy and Student Discontent: Chilean Student Protest in the PostPinochet Era, "Journal of Politics in Latin America", vol. 7 (3).

- (2017) Student Movement in Chile: Explaining a Protest Paradox, http://www.panoramas.pitt. edu/health-and-society/student-movement-chile-explaining-protest-paradox [dostęp: 12 września 2017].

Domańska Ewa (2007), „Zwrot performatywny” we wspótczesnej bumanistyce, „Teksty Drugie”, nr 5.

Elzenberg Henryk (1994), Kłopot z istnieniem. Aforyzmy w porzqadku czasu, Znak, Kraków.

Etzkowitz Henry (2002), MIT and the Rise of Entrepreneurial Science, Routledge, London.

Freeman Brigid, Marginson Simon, Tytler Russell (2014), The Age of STEM: Educational Policy and Practice Across the World in Science, Technology, Engineering and Mathematics, Routledge, London.

Grosse Tomasz G. (2008), Co dalej ze strategia liz̧bońska?, „Analizy i Opinie”, nr 84, Instytut Spraw Publicznych, Warszawa.

Heidegger Martin (2002), Odczyty i rozprawy, tłum. J. Mizera, Wydawnictwo Baran i Suszczyński, Kraków.

Hejwosz-Gromkowska Daria (2014), Czy nam sie oplaca? — o instrumentalnej orientacji w nauce. Kilka uwag zperspektywy bumanisty, „Liberté!”, nr 10/2014, Fundacja Industrial, Łódź.

Kahl Reinhard (2013), Kto czesto gra w teatrze, bedzie lepszy z. matematyki [w:] Edukacja. Przewodnik Krytyki politycznej, Wydawnictwo Krytyki Politycznej, Warszawa.

Kargulowa Alicja (2005), Pržemiany edukacyjnego rynku. Rynek (dla) zadowolonego konsumenta [w:] Rynek i kultura neoliberalna a edukacja, red. A. Kargulowa, S. M. Kwiatkowski, T. Szkudlarek, Oficyna Wydawnicza „Impuls”, Kraków.

Komercjalizacja edukacji. Konsekwencje i nowe zagrożenia (2010), red. M. Sysko, Ośrodek Myśli Społecznej im. Ferdynanda Lassalle’a, Wrocław-Warszawa.

Kozyr-Kowalski Stanisław (2005), Uniwersytet a rynek, Wydawnictwo UAM, Poznań.

Kwiek Marek (2015), Uniwersytet w dobie przemian. Instytucje $i$ kadra akademicka w warunkach rosnacej konkurencii, Naukowe PWN, Warszawa.

Lewartowska-Zychowicz Małgorzata (2010), Homo liberalis jako projekt edukacyjny. Od emancypacji do funk.cjonalności, Oficyna Wydawnicza „Impuls”, Kraków.

Mannheim Karl (2008), Ideologia i utopia, tłum. J. Miziński, Wydawnictwo Fundacji Aletheia, Warszawa.

Mayor Federico (1989), Culture and the University, ,Journal Higher Education in Europe”, vol. 14. Melosik Zbyszko (2009), Uniwersytet $i$ spoteczeństwo. Dyskursy wolności, wiedsy i władzy, Oficyna Wydawnicza „Impuls”, Kraków. 
Nevo Ofra, Nevo Baruch (1996), The Promotion Game, „Journal of Personal Evaluation in Education”, vol. 10.

Nussbaum Martha C. (2016), Nie dla zysku. Dlaczego demokracja potrzebuje bumanistów, tłum. Pawłowski Ł., Biblioteka Kultury Liberalnej, Warszawa.

Opiłowska Marta (2009), W spótczésni studenci jako stratedzy wtasnej kariery zawodowej (w świetle teorii gier i kredencjaliæmu), „Teraźniejszość - Człowiek — Edukacja”, nr 4(48).

Palacios-Valladares Indira (2016), Protest Communities and Activist Enthusiasm: Student Occupations in Contemporary Argentina, Chile and Uruguay, "A Journal for and About Social Movements", vol. 8 (2).

Prywatyzacja szkelnictwa wy:̇szego w Polsce (2000), red. B. Misztal, Stowarzyszenie Rektorów i Założycieli Uczelni Niepaństwowych, Kraków.

Ransby Barbara (2015), Students as Moral Teachers: A Survey of Student Activism and Institutional Res-ponses, https://www.aacu.org/diversitydemocracy/2015/fall/ransby [dostęp: 11 września 2017].

Rutkowiak Joanna (2008), Neoliberalizm jako kulturowy kontekst ksz̧tattowania sie tożsamości wspótczesnego nanczyciela (ku problematyce oporu i odporu edukacyjnego), „Teraźniejszość - Człowiek - Edukacja", nr 1(41).

Schmidt Peter (2014), Tasked to Protect All on Campus, but Accused of Racial Bias, https://www. nytimes.com/2014/12/29/us/tasked-to-protect-all-on-campus-but-accused-of-racial-bias. html?_r=0 [dostęp: 12 sierpnia 2017].

Schumpeter Joseph A. (2009), Kapitalizm, socjalizm, demokracja, tłum. M. Rusiński, Naukowe PWN, Warszawa.

Shore Cris, Wright Susan (2004), Whose accountability? Governmentality and the auditing of universities, „Paralax”, vol. 10(2).

- (2015), Governing by numbers. Audit culture, rankings and the new world order, "Social Anthropology/Anthropologie Sociale", vol. 23(1).

Sławek Tadeusz (2002), Antygona w świecie korporacji: roz̧ważania o uniwersytecie i czasach obecnych, Wydawnictwo UŚ, Katowice.

Sowa Jan (2014), Humanistyka plaskiego świata, „Teksty Drugie. Teoria literatury, krytyka, interpretacja", nr 1.

Strzemiński Władysław (2016), Teoria widzenia, red. nauk. I. Luba, Muzeum Sztuki w Lodzi, Łódź.

Szadkowski Krystian (2015), Uniwersytet jako dobro wspólne. Podstawy krytycznych badań nad sækolnictwem wy:şym, PWN, Warszawa.

Szkudlarek Tomasz (2007), Edukacja i konstruowanie społecznych nierówności [w:] Fenomen nierównosci społecznych, red. J. Klebaniuk, ENETEIA, Warszawa.

Torczyńska Monika (2013), Kryzys zaufania w relacjach społecznych a kapitat społeczny wspótczesnej demokracji [w:] Nauki spoteczne wobec krysysu i nowych wyzwań. Teoria i praktyka, red. nauk. Z. Dacko-Piukiewicz, I. Emmerova, Wydawnictwo Edukacyjne „AKAPIT”, Toruń.

Uniwersytet zaangażowany - zapomniana historia. Z Andrzejem Mencwelem rozmawia Stawomir Sierakowski. Uniwersytet zaangażowany (2010), Præewodnik. Krytyki Politycznej, Wydawnictwo Krytyki Politycznej, Warszawa.

Welch Anthony R. (1997), All change? The professoriate in uncertain times, „Higher education”, vol. 34 . 
Wilczyński Marek (2016), Driewię́ uwag o bumanistyce na uniwersytecie [w:] Humanistykea z widokiem na uniwersytet, red. M. Cieliczko, E. Nowicka, J. Wolska, Wydawnictwo Naukowe UAM, Poznań.

Wolność, równość, uniwersytet (2011), red. C. Kościelniak, J. Makowski, Instytut Obywatelski, Warszawa.

Wong Alia (2015), The Renaissance of Student Activism, https://www.theatlantic.com/education/ archive/2015/05/the-renaissance-of-student-activism/393749/ [dostęp: 20 sierpnia 2017]. 